\title{
THE EFFECT OF PANCURONIUM BROMIDE ON PLASMA NOREPINEPHRINE AND CORTISOL CONCENTRATIONS DURING THIAMYLAL INDUCTION
}

\author{
Elemér K. Zsigmond, m.D., Akitomo Matsuki, M.D., ${ }^{\circ}$ Sarla P. Kothary, M.d.; \\ and Robert C. KelsCh, M.D. $\dagger$ with the technical assistance of Louise Vadnay $\dagger$
}

The CARDIAC ${ }^{1-7}$ AND NEUROMUSCULAR ${ }^{8-10}$ blocking effects of pancuronium bromide have been widely studied; however, no information is available at present on the endocrine response to the administration of pancuronium, except for our previous report on cortisol concentrations during halothane anaesthesia. ${ }^{11}$ Therefore, the present study was undertaken to explore whether pancuronium has any infuence on the sympathetic nervous system and/or on adrenocortical function as reflected by peripheral plasma-free norepinephrine and cortisol levels during thiamylal$\mathrm{N}_{2} \mathrm{O}$ anaesthesia in man.

\section{Materials ANd Methods}

Eight patients were studied, ranging in age from 16 to 73 , with a mean age of 39 years. Seven were females and one was male. They were free from hepatic, renal and endocrine diseases and had no history of steroid therapy.

Pre-anaesthetic medication consisted of $10 \mathrm{mg}$ of diazepam, $10 \mathrm{mg}$ of morphine and $0.4 \mathrm{mg}$ of atropine sulfate intramuscularly one hour prior to induction of anaesthesia. Thiamylal was administered intravenously until the lid reflex disappeared, and the combination of nitrous oxide at a flow rate of $4 \mathrm{~L} / \mathrm{min}$ and oxygen at $2 \mathrm{~L} / \mathrm{min}$ was administered through a face mask. After ascertaining that the patient was asleep, a dose of $0.09 \mathrm{mg} / \mathrm{kg}$ of pancuronium was given intravenously over a ten-second period into a continuously rumning intravenous infusion. No intubation, no changes in position and no surgical preparations were allowed during this study period.

Anaesthesia was induced between 7:45 a.m. and 10:30 a.m. considering the circadian variation of plasma cortisol levels. Tracheal intubation was performed in all cases only after the completion of blood sampling. The arterial blood samples for determination of blood gases, plasma free norepinephrine and cortisol concentrations were taken, before and 2,5 and 10 minutes after the intravenous injection of pancuronium. An indwelling catheter in the brachial artery was used in the first four patients. Venous blood samples were collected from the antecubital vein in the other four patients, in lieu of arterial blood. Plasma cortisol concentrations and blood gases were, however, always determined in the arterial samples.

Department of Anaesthesiology ${ }^{\circ}$ and Department of Paediatrics $\dagger$ University of Michigan Medical Center, Ann Arbor, Michigan 48104, U.S.A. 


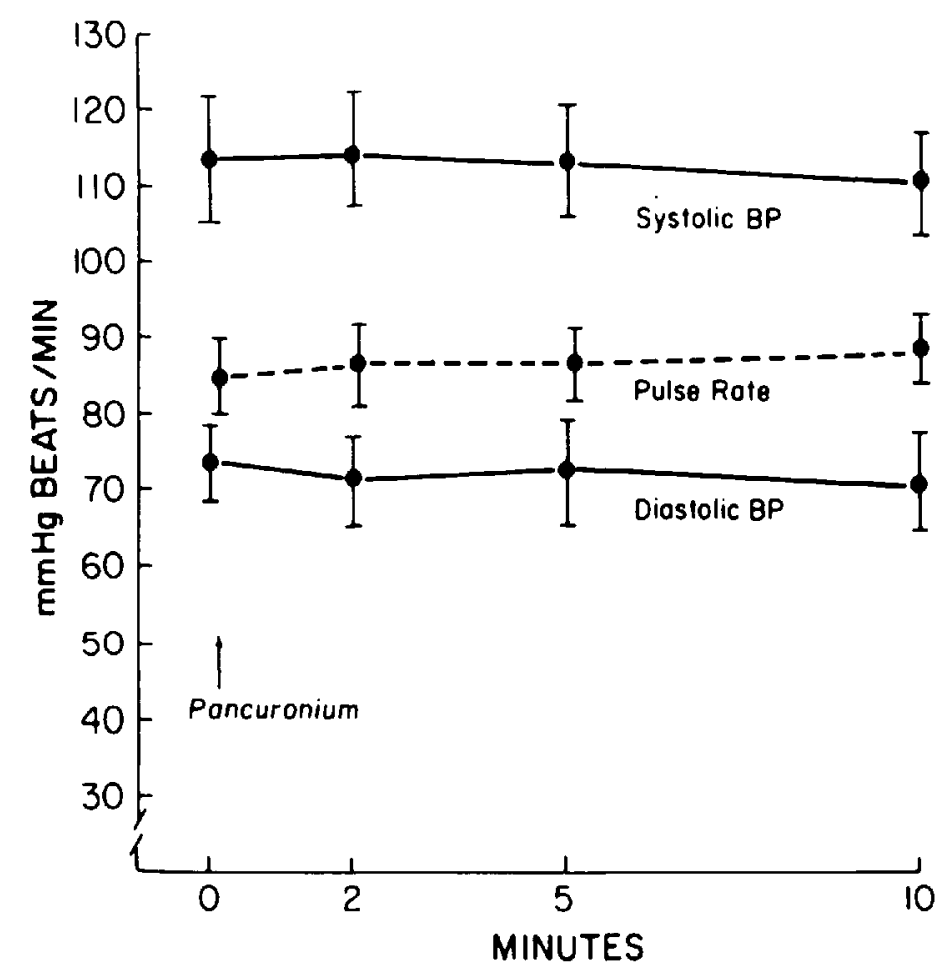

Ficure 1. Blood pressures and pulse rates after pancuronium administration.

Free norepinephrine concentrations in plasma were measured by Vendsalu's method as modified by Kelsch. ${ }^{12}$ Plasma cortisol was determined by Rudd's method. ${ }^{13}$ Arterial blood gas analyses were performed by Astrup's micromethod utilizing Siggard-Andersen nomogram. ${ }^{14}$

\section{Results}

\section{Circulatory changes}

The mean systolic and diastolic blood pressures of eight patients who received thiamylal followed 30 seconds later by pancuronium were $113 \pm 7.8 \mathrm{~mm} \mathrm{Hg}$ and $74 \pm 5.0 \mathrm{~mm} \mathrm{Hg}$ respectively. No significant $(\mathrm{p}>0.05)$ changes were observed at 2,5 and 10 min following the intravenous administration of pancuronium as illustrated in Figure 1. The changes in pulse rate paralleled the changes in blood pressure and were not significant $(\mathrm{p}>0.05)$.

\section{Plasma free norepinephrine concentrations}

No significant $(p>0.05)$ changes from the base line were detected in the plasma norepinephrine levels during the study period, as shown in Figure 2. Furthermore, there was no statistically significant difference between the mean arterial and the mean venous plasma concentrations of norepinephrine in the two groups of four patients studied.

\section{Plasma cortisol concentrations}

As illustrated in Figure 2, there were no significant $(p>0.05)$ changes in the plasma cortisol concentrations. 


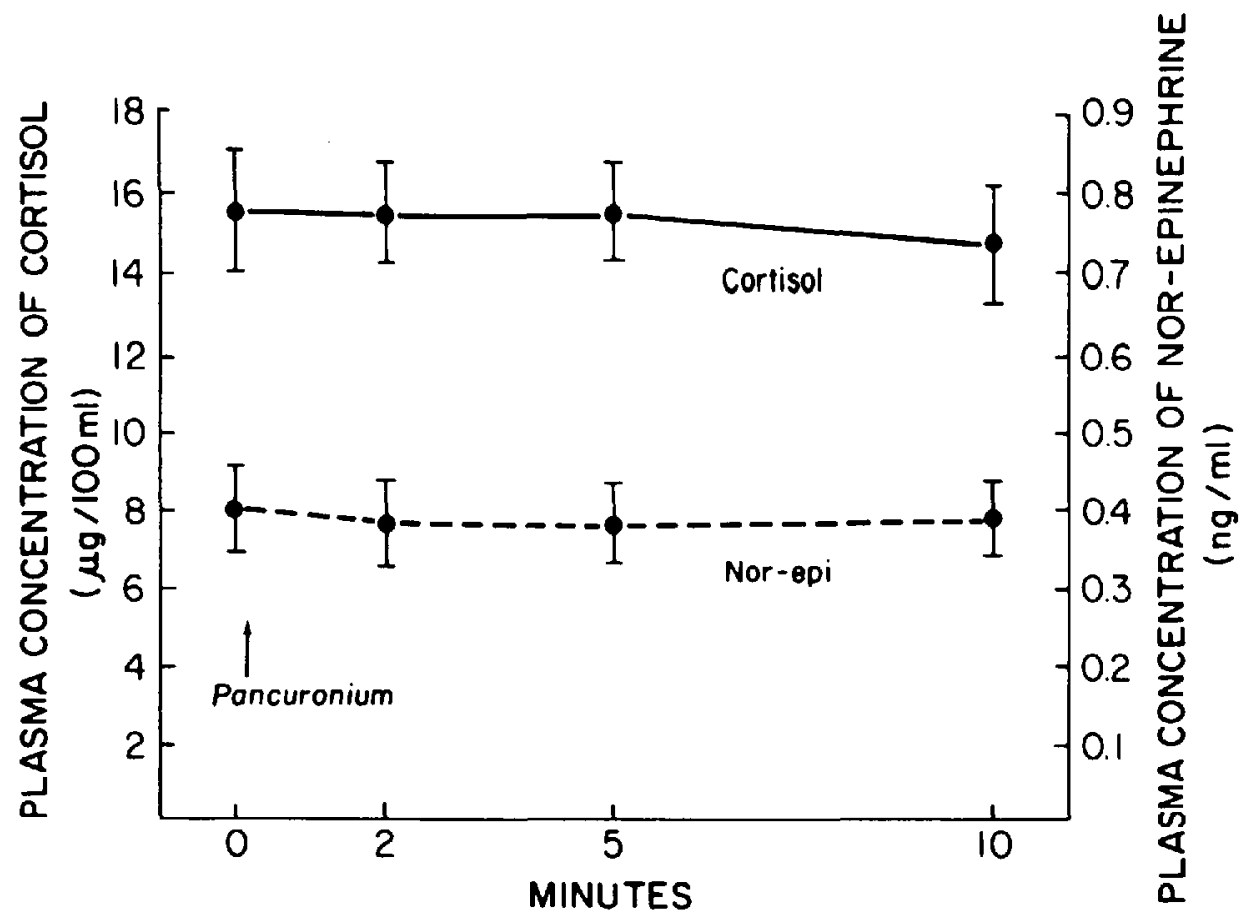

Ficure 2. Plasma concentrations of free norepinephrine and cortisol after pancuronium administration.

\section{Arterial blood gas analyses}

Simultaneous analyses of the arterial blood gases substantiated neither respiratory nor metabolic abnormalities.

\section{Discussion}

Pancuronium bromide has been reported to cause a slight increase in the mean systolic blood pressure ${ }^{1-\overline{5}}$ and the pulse rate both in experimental animals and in surgical patients, while several investigators ${ }^{10.15}$ have failed to confirm these results. The discrepancy might be explained by the differences in premedications, anaesthetics, and the experimental designs.

In the present study, the mean systolic blood pressure remained unchanged at five and ten minutes following the intravenous injection of thiamylal and pancuronium while in a previous study, ${ }^{16}$ Zsigmond found a significant $(\mathrm{p}<$ $0.01)$ fall in the systolic blood pressure at five minutes $(-18.5 \mathrm{~mm} \mathrm{Hg})$ and ten minutes $(-25 \mathrm{~mm} \mathrm{Hg})$ following intravenous administration of thiamylal alone. Therefore, pancuronium evidently counteracts hypotension caused by thiamylal. These findings tend to corroborate the report of $\mathrm{McD}$ owell and Clarke ${ }^{17}$ and Bonta, Goorissen and Derk ${ }^{18}$ that pancuronium counteracted hypotension caused by halothane inhalation.

Bonta, Goorissen and Derk ${ }^{18}$ reported that pancuronium has a selective vagolytic action on the cardiac nerve terminals. Recently Saxena and Bonta ${ }^{18}$ demonstrated that pancuronium may specifically block the cardiac muscarinic receptors, 
which may explain the cardiac effects of pancuronium. On the contrary, Loh ${ }^{1}$ suggested that pancuronium may stimulate the sympathetic ganglia or that it may have a direct positive inotropic effect on the heart muscle. In our study, the mean plasma norepinephrine levels were unaltered at 2,5 and 10 minutes following the administration of intravenous thiamylal and pancuronium. Therefore, a sympathomimetic effect of pancuronium is unlikely to be responsible for its circulatory effects.

In order to rule out the possibility that thiamylal given prior to pancuronium might have blocked the rise in plasma norepinephrine, we also determined plasma free norepinephrine concentrations during anaesthetic induction with ketamine in combination with pancuronium. The preliminary results further confirm a lack of increase in free norepinephrine in response to administration of this combination.

Komesaroff also suggested that the increase in blood pressure and pulse rate was caused by a mechanism similar to that initiated by gallamine. We previously reported ${ }^{20}$ that an intravenous dose of $40-80 \mathrm{mg}$ of gallamine caused a significant $(p<0.025)$ increase in the plasma norepinephrine levels in patients induced with halothane. This implies that circulatory effects of gallamine are likely to be caused by a combination of cardiac vagolytic action and elevated plasma norepinephrine levels. Our findings on the lack of plasma norepinephrine rise together with the findings of other investigators on the low incidence of histamine release $^{21}$ and the lack of evidence for ganglion blocking effect in men ${ }^{22}$ may further explain the remarkable cardiovascular stability observed with pancuronium even in critically ill patients.

According to Oyama and his associates, ${ }^{23.24}$ thiopentone per se reduces plasma cortisol levels significantly at 15 and 30 minutes following induction. In the present study, as expected, no appreciable changes were detected in the plasma cortisol levels at 2, 5 and 10 minutes. Previously, however, Matsuki and Oyama ${ }^{11}$ found no increase in cortisol levels even later, at 15 and 30 minutes following administration of pancuronium during halothane anaesthesia without barbiturate induction. Their results complement the findings in the present study.

\section{Summary and Conclusion}

Effects of pancuronium on free norepinephrine and cortisol concentrations in plasma were investigated in eight elective surgical patients. A dose of $0.09 \mathrm{mg} / \mathrm{kg}$ of pancuronium was administered intravenously following thiamylal induction during nitrous oxide-oxygen inhalation and prior to intubation and surgical preparation. No hypoxic or hypercarbic episodes were demonstrated by arterial blood gas studies.

No significant changes from the base line level were observed either in free norepinephrine levels or in plasma cortisol levels for ten minutes following the administration of pancuronium. Although pancuronium did not cause a rise in free norepinephrine concentration in plasma, it counteracted the hypotension usually observed following the intravenous administration of thiamylal. Heart rate and blood pressure, however, were not significantly increased. 


\section{RÉSUMÉ}

Les effets du Pancuronium sur la concentration de Norépinéphrine et de Cortisol dans le plasma, furent étudiés chez huit patients électifs. Après une induction au Thiamylal, précédant l'intubation endotrachéale et la préparation chirurgicale, une dose de $0.09 \mathrm{mg} / \mathrm{kg}$ de Pancuronium fut administrée sous Protoxyde-Oxygène. Aucun épisode hypoxique ou hypercarbique ne fut démontré par l'étude du sang artériel.

Aucun changement significatif ne fut observé dans la concentration plasmatique de la Norépinéphrine ou du Cortisol pendant les dix minutes suivant ladministration du Pancuronium. Même si le Pancuronium ne provoque pas d'élévation de la Nor-épinéphrine plasmatique libre, il annulle l'hypotension habituellement observée après administration intra-veineuse de Thiamylal. Le rythme cardiaque et la tension artérielle ne se sont pas élevés de façon significative.

\section{ACKNOWLEDGMENTS}

We are grateful in acknowledging the Staff of the Department of Obstetrics and Gynaecology for allowing us to study their patients.

\section{REFERENCES}

1. Lor, L. The cardiovascular effects of pancuronium bromide. Anaesthesia 25: $356-363$ (1970)

2. Smith, G., Proctor, D.W., \& Spence, A.A. A comparison of some cardiovascular effects of tubocurarine and pancuronium in dogs. Brit. J. Anaesth, 42: 923-927 (1970).

3. Kelman, G.R. \& Kennedy, B.R. Cardiovascular effects of pancuronium in man. Brit. J. Anaesth. 43: 335-338 (1971).

4. Stoelting, R.K. The hemodynamic effects of pancuronium and d-tubocurarine in anesthetized patients. Anesthesiology 36: 612-615 (1972).

5. Gentel, M., Fox, G.S., Rabow, F.I, \& Graham, D.H. The cardiovascular effects of pancuronium bromide during halothane anaesthesia. Canad. Anaes. Soc. J. 19: 599-606 (1972).

6. KomesarofF, D. Further clinical studies on pancuronium bromide. 2. A study of the effects on the blood pressure and pulse rate. Med. J. Australia 1: 497-499 (1970).

7. Levin, N. \& Dillon, J.B. Cardiovascular effects of pancuronium bromide. Anes. \& Analg. 50: 808-812 (1971).

8. Katz, R.L. Clinical neuromuscular pharmacology of pancuronium. Anesthesiology 34 : $550-556$ (1971).

9. Foldes, F.F., Klonymus, D.H., Maisel, W., Sciammas, F., \& Pan, T. Studies of pancuronium in conscious and anesthetized man. Anesthesiology 35: 496-503 (1971).

10. BaIRD, W.L.M. \& ReID, A.M. The neuromuscular blocking properties of a new steroid compound, pancuronium bromide, a pilot study in man. Brit. J. Anaesth. 39: 775-780 (1967).

11. Matsuxi, A. \& Oyama, T. Adrenocortical function related to administration of muscle relaxants during halothane anesthesia in man. Agressologie 12: 283-289 (1971).

12. Kelsch, R.C., Light, G.S., Luciano, J.R., \& Oliver, W.J. The effects of prednisone on plasma nor-epinephrine concentration and renin activity in salt-depleted man. J. Lab. Clin. Med. 77: 267-277 (1971).

13. Rudd, B.T., Cowper, J.M., \& Chawfond, N. The determination of plasma-free hydrocortisone and corticosterone by a combined fluorimetric and modified Porter-Silber procedure. Clin. Chem. Acta 6: 686-695 (1961).

14. Astrup, P., Jørgensen, K., Siggard-Andersen, O., \& Engel, K. The acid-base metabolism, a new approach. Lancet $1: 1035-1039$ (1960).

15. Norman, J., Katz, R.L., \& SEED, R.F. The neuromuscular blocking action of pancuronium in man during anaesthesia. Brit. J. Anaesth. 42: 702-710 (1970). 
I6. Zsigmond, E.K. Comment on G. Corssen's paper entitled "Ketamine in anesthetic management of asthmatic patients" Anesth. Analg, 51: 595-596 (1972).

17. McDowell, S.A. \& ClAKK, R.S. A clinical comparison of pancuronium with d-tubocurarine. Anaesthesia 24: 581-590 (1969).

18. Bonta, I.L., Goonissen, E.M., \& DERK, F.H. Pharmacological interaction between pancuronium bromide and anesthetics. Eur. J. Pharmacol. 4: 83-90 (1968).

19. Saxena, P.R. \& Bonta, I.L. Mechanism of selective cardiac vagolytic action of pancuronium bromide, specific blockade of cardiac muscarinic receptors. Eur. J. Pharmacol. 11: 332-341 (1970).

20. Matsuki, A., Kothahy, S.P., \& Zsigmond, E.K. Effects of Gallamine on plasma cortisol and catecholamine concentrations in man. Canad. Anaesth. Soc. J., 20: 539-545 (1973),

21. Fukushima, K. \& Miyashita, K. Histamine blood levels following intravenous administration of pancuronium bromide in anesthetized subjects. Symposium on pancuronium bromide. September 14, 1970, Tokyo, Japan.

22. Buckett, W.R., Marjoribanks, C.E.B., Marwick, F.A., \& Monton, M.B. The pharmacology of pancuronium bromide (ORC NA97), a new potent steroid muscular blocking agent. Brit. J. Pharmacol. 32: 671-682 (1968).

23. Orama, T., Takiguchi, M., AKI, N., \& Kudo, T. Aclrenocortical function related to thiopental-nitrous oxide-oxygen anesthesia and surgery in man. Anesth. Analg. 50: 727-731 (1971).

24. Ovama, T., Matsumoto, F., \& Kudo, T. Effects of ketamine on adrenocortical function in man. Anesth. Analg. 49:679-700 (1970). 